\title{
JIMMBA
}

Jurnal Ilmiah Mahasiswa Manajemen, Bisnis dan Akuntansi

Homepage: $h$ ttp://journal.stieputrabangsa.ac.id/index.php/jimmba/index

\section{Pengaruh Profitabilitas, Good Corporate Governance dan Intensitas Modal Terhadap Penghindaran Pajak pada Perusahaan Pertambangan Sektor Batu Bara di Bursa Efek Indonesia Periode 2016-2018}

\author{
Eka Murni Lusiana Wati ${ }^{1}$, Susi Astuti ${ }^{2}$ \\ ${ }^{1}$ Sekolah Tinggi Ilmu Ekonomi Putra Bangsa \\ 2 Sekolah Tinggi Ilmu Ekonomi Putra Bangsa \\ Email : ekamurnilusianawati@gmail.com
}

\section{ARTICLE INFO}

Article History:

Received: July $20^{\text {th }} 2020$

Accepted: August 1 ${ }^{\text {st }} 2020$

Published: August 31st 2020

Keywords:

Profitabilitas, Return On

Assets, Good Corporate

Governance, Kepemilikan

Institusional, Dewan

Komisaris Independen,

Intensitas Modal,

Penghindaran Pajak

\begin{abstract}
Penelitian ini bertujuan untuk mengetahui pengaruh profitabilitas, good corporate governace, dan intensitas modal terhadap penghindaran pajak yang diproksikan dengan cash effective tax rate (CETR) pada perusahaan pertambangan sektor batu bara yang terdaftar di Bursa Efek Indonesia (BEI). Mekanisme profitabilitas yang digunakan adalah return on asset, good corporate governance yang digunakan adalah proporsi kepemilikan institusional dan dewan komisaris independen, intensitas modal yang digunakan adalah capital intensity. Populasi dalam penelitian ini adalah seluruh perusahaan pertambangan sektor batu bara yang terdaftar Bursa Efek Indonesia (BEI) tahun 2016 sampai 2018. Sedangkan sampel penelitian ini ditentukan dengan metode purposive sampling sehingga diperoleh 45 perusahaan sampel. Jenis data yang digunakan adalah data sekunder yang diperoleh dari www.idx.co.id. Metode analisis yang digunakan adalah analisis regresi berganda. Berdasarkan hasil analisis regresi berganda maka hasil penelitian ini yaitu return on assets, dewan komisaris independen berpengaruh negatif terhadap penghindaran pajak yang diproksikan dengan cash effective tax rate, sedangan kepemilikan institusional, intensitas modal tidak berpengaruh terhadap penghindaran pajak yang diproksikan dengan cash effective tax rate.
\end{abstract}

\section{Pendahuluan}

Sumber penerimaan negara berasal dari berbagai sektor, baik sektor internal maupun eksternal. Salah satu sumber penerimaan negara dari sektor internal adalah pajak, sedangkan sumber penerimaan dari sektor eksternal adalah pinjaman luar negeri. Bagi Indonesia, penerimaan negara yang berasal dari pajak masih menjadi penerimaan terbesar bagi Anggaran Pendapatan dan Belanja Negara (APBN). Oleh karena itu, pajak selalu menjadi fokus pemerintah karena pajak menjadi tumpuan terbesar dalam Anggaran 
Pendapatan dan Belanja Negara (APBN). Besarnya peranan pajak bagi negara sesuai dengan data yang dipublikasikan oleh Badan Pusat Statistik (BPS) bersumber dari penerimaan pajak, sedangkan sisanya berasal dari bukan pajak dan hibah.

Tabel 1. Realisasi Penerimaan Negara Tahun 2016-2018

(dalam miliyaran rupiah)

\begin{tabular}{|l|c|c|c|}
\hline $\begin{array}{c}\text { Sumber } \\
\text { Penerimaan }\end{array}$ & $\mathbf{2 0 1 6}$ & $\mathbf{2 0 1 7}$ & $\mathbf{2 0 1 8}$ \\
\hline Pajak & $1.284 .970,10$ & $1.343 .529,80$ & $1.548 .485,00$ \\
\hline Bukan Pajak & $261.976,30$ & $311.216,30$ & $349.158,30$ \\
\hline Hibah & $8.987,70$ & $11.629,80$ & $5.383,20$ \\
\hline
\end{tabular}

Sumber: Badan Pusat Statistik, 2019.

Dilihat dari tabel diatas, sumber penerimaan terbesar negara bersumber dari penerimaan pajak, hal ini membuktikan bahwa pajak sangat penting yang berguna untuk memenuhi kebutuhan negara dan pajak mempunyai peran serta berkontribusi dalam meningkatkan pembangunan nasional. Dari sudut pandang pemerintah, wajib pajak diharapkan melaksanakan kewajiban perpajakan semaksimal mungkin. Penerimaan negara dari sektor pajak akan bertambah dan sebaliknya jika pajak yang dibayarkan oleh wajib pajak lebih kecil, maka pendapatan negara dari sektor pajak akan berkurang.

Fenomena penghindaran pajak di Indonesia tidak hanya ditemukan pada sektor usaha dan ekonomi tetapi pada sektor pertambangan batu bara melakukan tindakan penghindaran pajak. Perusahaan tambang terbesar di Indonesia yaitu PT Adaro Energy Tbk melakukan penghindaran pajak, Adaro melakukan transfer pricing atau pengalihan keuntungan dari Indonesia ke negara lain melalui anak usahanya di Singapura, Coaltrade Services International sejak tahun 2009 hingga 2017. Adaro telah mengalihkan pendapatan dan labanya ke luar negeri sehingga menekan pajak yang dibayarkan kepada pemerintah Indonesia, Adaro membayar pajaknya sebesar \$125 juta juta lebih rendah dari keuntungan yang didapatkan hasil penjualan batu bara sebesar $90 \%$ atau $\$ 338$ juta dan Adaro mengurangi tagihan pajak di Indonesia hampir \$14 juta per tahun. (www.detikfinance.com)

\section{Kajian Teori dan Telaah Literatur}

\section{Agency Theory}

Teori ini muncul karena adanya hubungan antara principals dan agent. Teori agensi merupakan konsep yang menjelaskan hubungan kontraktual antara principals dan agent. Pihak principals adalah pihak yang memberikan mandat kepada pihak lain, yaitu agent, untuk melakukan semua kegiatan atas nama principals dalam kapasitasnya sebagai pengambil keputusan (Hidayah, et.al, 2017). Tujuan dari teori agensi adalah untuk meningkatkan kemampuan individu (baik principal maupun agent) dalam mengevaluasi lingkungan dimana keputusan harus diambil. Tujuan yang lain yaitu untuk mengevaluasi hasil dari keputusan yang telah diambil guna mempermudah pengalokasian hasil antara principal dan agent sesuai dengan kontrak kerja. 


\section{Perencanaan Pajak}

Perencanaan pajak adalah rangkaian untuk mengatur akuntansi dan keuangan perusahaan untuk meminimalkan kewajiban perpajakan dengan cara-cara yang tidak melanggar peraturan perpajakan, dalam arti luas tax planning adalah keseluruhan fungsi manajemen perpajakan (Pohan, 2017:5). Tujuan perencanan pajak adalah untuk merekayasa usaha wajib pajak agar beban pajak dapat ditekan serendah mungkin dengan memanfaatkan celah-celah peraturan perpajakan yang ada untuk memaksimalkan jumlah laba setelah pajak, karena dalam hal ini pajak merupakan unsur pengurang laba.

\section{Pajak}

Pajak menurut Undang-Undang Nomor 16 tahun 2009 tentang Ketentuan Umum dan Tata Cara Perpajakan pada Pasal 1 ayat 1 merupakan kontribusi wajib kepada negara yang terutang oleh orang pribadi atau badan yang bersifat memaksa berdasarkan undang-undang, dengan tidak mendapatkan imbalan secara langsung dan digunakan untuk keperluan negara bagi sebesar-besarnya kemakmuran rakyat. Pajak merupakan pungutan negara yang ditujukan kepada wajib pajak, baik perseorangan maupun badan, sebagai bentuk partisipasi dalam meningkatkan laju pertumbuhan dan pelaksanaan pembangunan nasional demi mencapai kesejahteraan negara (Santoso, 2014).

\section{Penghindaran Pajak}

Penghindaran pajak adalah upaya penghindaran pajak yang dilakukan secara legal dan aman bagi wajib pajak karena tidak bertentangan dengan ketentuan perpajakan, dimana metode dan teknik yang digunakan cenderung memanfaatkan kelemahan-kelemahan (grey area) yang terdapat dalam undang-undang dan peraturan perpajakan itu sendiri untuk memperkecil jumlah pajak yang terutang (Pohan 2013:23). Tujuan penghindaran pajak adalah menekan atau meminimalisasi jumlah pajak yang harus dibayar.

$$
\text { CETR }=\frac{\text { Pembayaran Pajak }}{\text { Laba Sebelum Pajak }} \times 100 \%
$$

\section{Profitabilitas}

Profitabilitas merupakan salah satu pengukuran bagi kinerja suatu perusahaan. Profitabilitas adalah ukuran kemampuan perusahaan perseorangan atau badan untuk menghasilkan laba dengan memperhatikan modal yang digunakan. Return On Assets (ROA) adalah rasio profitabilitas yang dapat membandingkan laba bersih dengan total aset pada akhir periode, yang digunakan sebagai indikator kemampuan perusahaan dalam menghasilkan laba. (Dewinta, 2016).

$$
R O A=\frac{\text { Laba Setelah Pajak }}{\text { Total Aset }} \times 100 \%
$$

\section{Kepemilikan Institusional}

Kepemilikan Institusional merupakan saham perusahaan yang dimiliki oleh institusi atau lembaga non Bank. Kepemilikan Institusional diharapkan mampu meminimalkan konflik keagenan karena manajer diharapkan bisa membuat keputusan utang dan dividen yang berpihak pada kepentingan pemegang saham institusional ini (Uun dan Puput, 2015). Kepemilikan Institusional dalam suatu perusahaan akan mendorong peningkatan pengawasan agar lebih optimal terhadap kinerja manajemen, karena kepemilikan saham 
mewakili suatu sumber kekuasaan yang dapat digunakan untuk mendukung atau tidak mendukung terhadap manajemen.

$$
K I=\frac{\text { Jumlah Saham Yang Dimiliki Institusi }}{\text { Jumlah Saham Yang Beredar }} \times 100 \%
$$

\section{Dewan Komisaris Independen}

Komisaris independen adalah anggota dewan komisaris yang tidak terafiliasi dengan direksi, anggota dewan komisaris lainnya dan pemegang saham pengendali, serta bebas dari hubungan bisnis atau hubungan lainnya yang dapat mempengaruhi kemampuannya untuk bertindak independen atau bertindak semata-mata demi kepentingan perusahaan (Sari, 2014). Dewan Komisaris Independen adalah organ perseroan yang bertugas melakukan pengawasan secara umum atau khusus sesuai dengan anggaran dasar serta memberi nasihat kepada direksi (Hanifi dan Halim, 2012).

$$
\text { DKI }=\frac{\text { Jumlah Komisaris Independen }}{\text { Jumlah Dewan Komisaris }} \times 100 \%
$$

\section{Intensitas Modal}

Intensitas modal adalah salah satu bentuk keputusan perusahaan dalam menginvestasikan asetnya berupa aset tetap. Aset tetap yang dimiliki perusahaan memungkinkan perusahaan memotong pajak akibat dari penyusutan aset tetap perusahaan setiap tahunnya. Biaya penyusutan ini adalah biaya yang dapat dikurangkan dari penghasilan, sehingga semakin besar biaya penyusutan akan semakin kecil tingkat pajak yang harus dibayarkan perusahaan (Rodrigues dan Arias, 2012).

$$
C I=\frac{\text { Total Aset Tetap }}{\text { Total Aset }} \times 100 \%
$$

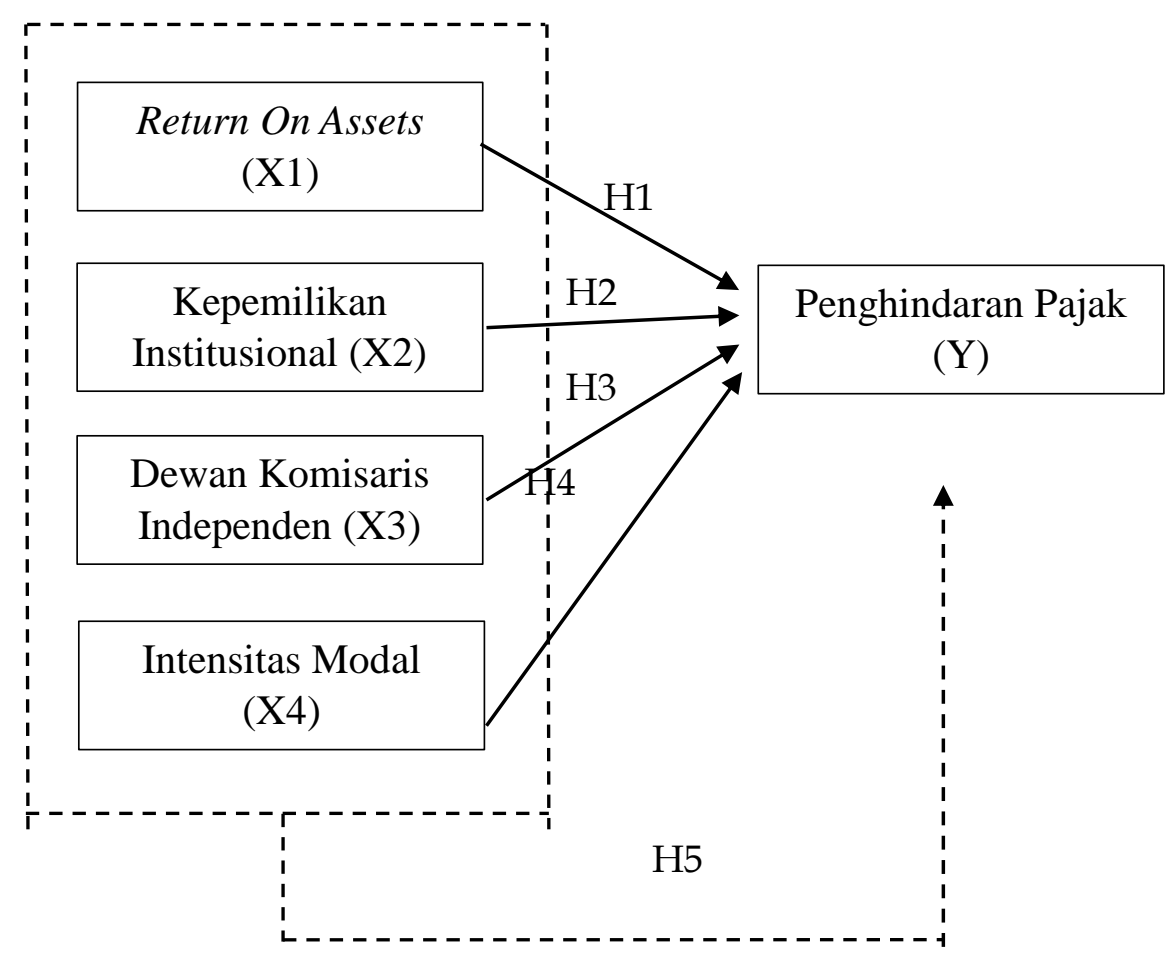

Gambar 1. Kerangka Hipotesis 
$\mathbf{H}_{\mathbf{1}}$ : Return On Assets berpengaruh negatif terhadap Penghindaran Pajak

$\mathbf{H}_{\mathbf{2}}$ : Kepemilikan Institusional berpengaruh positif terhadap Penghindaran Pajak

$\mathbf{H}_{3}$ : Dewan Komisaris Independen berpengaruh negatif terhadap Penghindaran Pajak

$\mathbf{H}_{4}$ : Intensitas Modal berpengaruh positif terhadap Penghindaran Pajak

$\mathbf{H}_{5}$ : Return On Assets, Kepemilikan Institusional, Dewan Komisaris Independen dan Intensitas Modal berpengaruh secara simultan terhadap Penghindaran Pajak

\section{Metode Penelitian}

\section{Sampel dan data}

Metode pengambilan sampel pada penelitian ini menggunakan metode purposive sampling. Adapun kriteria sampel yang digunakan dalam penelitian ini adalah 1) Perusahaan yang terdaftar di Bursa Efek Indonesia (BEI) selama tahun 2016-2018. 2) Perusahaan yang tidak mengalami delisting selama tahun 2016-2018. 3) Perusahaan yang mempublikasikan laporan tahunan dan laporan keuangan secara berturut-turut di Bursa Efek Indonesia (BEI) selama tahun 2016-2018. 4) Perusahaan yang tidak mengalami kerugian selama tahun 2016-2018.

Data yang digunakan dalam penelitian ini yaitu data sekunder. Data sekunder tersebut berupa laporan keuangan dari Pertambangan Sektor Batu Bara yang diperoleh dari situs Bursa Efek Indonesia periode 2016-2018, situs yang digunakan adalah www.idx.co.id, selain itu dilakukan juga studi pustaka yaitu pengumpulan data dengan cara mempelajari dan memahami buku-buku, jurnal yang berkaitan dengan penelitian.

\section{Hasil dan Pembahasan}

\section{Statistik Deskriptif}

Analisis statistik deskriptif memberikan gambaran atau deskriptif suatu data yang dilihat dari nilai-nilai (mean), standar deviasi, varian, maksimum, minimum, sum, range, kurtosis, dan swekness (kemencengan distribusi) (Ghozali, 2013:19).

Tabel 2. Descriptive Statistics

\begin{tabular}{lrrrrr}
\hline & & & & \multicolumn{1}{c}{$\begin{array}{c}\text { Std. } \\
\text { Deviation }\end{array}$} \\
\hline ROA & & Minimum & Maximum & \multicolumn{1}{c}{ Mean } & \multicolumn{1}{c}{ Devis } \\
KI & 45 &, 14 & 45,56 & 11,3558 & 11,42923 \\
DKI & 45 & 5,36 & 525,09 & 88,5209 & 105,74494 \\
CI & 45 & 16,67 & 66,67 & 40,2587 & 10,89565 \\
CETR & 45 &, 62 & 59,27 & 25,9567 & 14,94519 \\
Valid N & 45 & 4,72 & 353,25 & 56,6622 & 68,57286 \\
(listwise) & 45 & & & & \\
\hline
\end{tabular}

Sumber; Data yang diolah menggunakan SPSS 25, 2019.

Berdasarkan tabel 2 jumlah data $(\mathrm{N})$ sebesar 45, dari 15 sampel perusahaan pertambangan sektor batu bara yang terdaftar di BEI selama periode 3 tahun yaitu tahun 2016-2018. CETR (Y) memiliki nilai minimum sebesar 4,72 yaitu pada PT Harum Energy Tbk pada tahun 2016 dan nilai maximum sebesar 353,25 yaitu pada PT Darma Henwa Tbk pada tahun 2018. Nilai rata-rata sebesar 56,6622 dan nilai standar deviasi CETR sebesar 68,57286.

Return On Assets (ROA) memiliki nilai minimum sebesar 0,14 yaitu PT Darma Henwa Tbk pada tahun 2016 dan nilai maximum sebesar 45,56 yaitu PT Byan Resources Tbk pada tahun 2018. Nilai rata-rata sebesar 11,3558 dan standar deviasi 11,42923. 
Kepemilikan Institusional (KI) memiliki nilai minimum sebesar 5,36 yaitu PT Baramukti Suksessarana Tbk pada tahun 2018 dan nilai maximum sebesar 525,09 yaitu PT Delta Dunia Makmur Tbk pada tahun 2017. Nilai rata-rata sebesar 88,5209 dan standar deviasi 105,74494.

Dewan Komisaris Independen (DKI) memiliki nilai minimum sebesar 16,67 yaitu PT Baramukti Suksessarana Tbk pada tahun 2016 dan nilai maximum sebesar 66,67 yaitu PT Delta Dunia Makmur Tbk pada tahun 2017. Nilai rata-rata sebesar 40,2587 dan standar deviasi 10,89565 .

Intensitas Modal (CI) memiliki nilai minimum sebesar 0,62 yaitu PT Bumi Resources Tbk pada tahun 2018 dan nilai maximum sebesar 59,27 yaitu PT Petrosea Tbk pada tahun 2016. Nilai rata-rata sebesar 25,9567 dan standar deviasi 14,94519.

\section{Uji Asumsi Klasik}

\section{Uji Normalitas}

Uji normalitas digunakan untuk menguji kenormalan pendistribusian dalam model regresi, variabel pengganggu atau residualnnya (Ghozali, 2018: 161). Pengujian normalitas dilakukan dengan menggunakan Teknik Kolmogorov-Smirnov Test.

Tabel 3. Uji Normalitas

One-Sample Kolmogorov-Smirnov Test

\begin{tabular}{llr}
\hline & & Unstandardized Residual \\
\hline Normal Parametersa,b & Mean & 45 \\
& Std. Deviation &, 0000000 \\
Most Extreme Differences & Absolute &, 75372434 \\
& Positive &, 103 \\
& Negative &, 054 \\
Test Statistic & &,- 103 \\
Asymp. Sig. (2-tailed) & &, 103 \\
& &, $200 \mathrm{c,d}$ \\
\hline
\end{tabular}

Sumber; Data yang diolah menggunakan SPSS 25, 2019.

Berdasarkan tabel 3 yang berkaitan dengan uji normalitas melalui pendekatan statistik Kolmogorov-Smirnov, dapat dilihat bahwa nilai signifikansi sebesar 0,200 > 0,05, maka hasil tersebut menunjukkan bahwa data dalam penelitian ini terdistribusi normal, sehingga dapat disimpulkan bahwa model regresi dalam penelitian ini memenuhi asumsi normalitas.

\section{Uji Multikolinearitas}

Multikolinearitas adalah adanya suatu hubungan linier yang sempurna antara beberapa atau semua variabel independen. Uji multikolinieritas bertujuan untuk menguji apakah terdapat hubungan antar variabel independen dalam model regresi (Ghozali, 2012) karena model regresi yang baik adalah yang tidak terjadi korelasi diantara variabel independen. 
Tabel 4. Uji Multikolinearitas Coefficientsa

\begin{tabular}{llll}
\hline \multirow{2}{*}{ Model } & \multicolumn{3}{c}{ Collinearity Statistics } \\
\hline 1 & (Constant) & & VIF \\
& ROA &, 755 & \\
& KI &, 751 & 1,324 \\
& DKI &, 887 & 1,331 \\
& CI &, 819 & 1,128 \\
& & & 1,220 \\
\hline
\end{tabular}

a. Dependent Variable: CETR

Sumber; Data yang diolah menggunakan SPSS 25, 2019.

Model regresi dinyatakan bebas dari multikolinearitas jika mempunyai nilai VIF $<10$ dan nilai Tolerance $>0,10$. Dari tabel di atas diperoleh hasil semua variabel independen memiliki nilai VIF lebih kecil dari 10 dan nilai $\mathrm{T}$ lebih besar dari 0,10, sehingga dapat disimpulkan bahwa tidak ada multikolinearitas dalam model regresi.

\section{Uji Autokorelasi}

Uji autokorelasi digunakan untuk mengetahui apakah dalam model regresi linear terdapat korelasi antara kesalahan pada periode $t$ dengan kesalahan pengganggu periode $t-1$ (sebelumnya). Regresi yang baik adalah regresi yang tidak terjadi autokorelasi (Wijayanti, 2017).

Tabel 5. Uji autokorelasi

Runs Test

\begin{tabular}{lr}
\hline & Unstandardized Residual \\
\hline Test Value &, 09752 \\
Cases $<$ Test Value & 22 \\
Cases $>=$ Test Value & 23 \\
Total Cases & 45 \\
Number of Runs & 17 \\
Z & $-1,807$ \\
Asymp. Sig. (2-tailed) &, 071 \\
\hline
\end{tabular}

a. Median

Sumber; Data yang diolah menggunakan SPSS 25, 2019.

Hasil run test menunjukkan bahwa nilai signifikansi 0,071 > 0,05 yang berarti H0 ditolak, dapat disimpulkan bahwa data yang digunakan random sehingga tidak terdapat gejala autokorelasi dalam model regresi.

\section{Heterokedastisitas}

Heterokedastisitas adalah kesamaan varians dari residual. Uji heteroskedastisitas bertujuan menguji apakah dalam model regresi terjadi ketidaksamaan varians dari residual satu pengamatan ke pengamatan yang lain (Ghozali, 2012). 


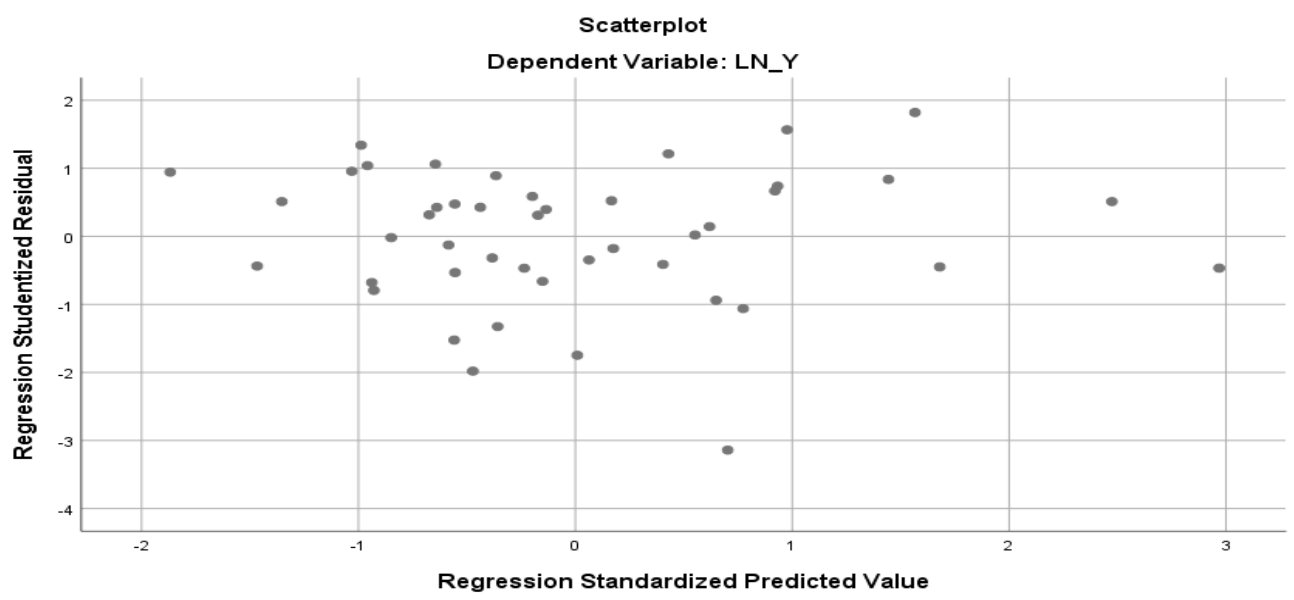

Sumber; Data yang diolah menggunakan SPSS 25, 2019.

Berdasarkan grafik Scatterplot diatas terlihat bahwa titik-titik menyebar secara acak tersebar baik diatas maupun dibawah angka 0 disumbu Y. Hal ini dapat disimpulkan bahwa tidak terjadi heterokedastisitas pada model regresi dalam penelitian ini.

\section{Regresi Linear Berganda}

Analisis regresi bertujuan untuk mengukur kekuatan hubungan antara dua variabel atau lebih serta untuk menunjukkan arah hubungan antara variabel dependen dengan variabel independen (Ghozali, 2018: 94).

\section{Tabel 6. Regresi Linear Berganda} Coefficients

\begin{tabular}{llrrrrr}
\hline \multicolumn{7}{c}{$\begin{array}{c}\text { Unstandardized } \\
\text { Coefficients }\end{array}$} \\
Model & \multicolumn{2}{c}{$\begin{array}{c}\text { Standardized } \\
\text { Coefficients } \\
\text { B }\end{array}$} & Std. Error & Beta & \multicolumn{1}{c}{ T } & \multicolumn{1}{c}{ Sig. } \\
\hline 1 & (Constant) & 8,276 & 1,803 & & 4,591 &, 000 \\
& ROA &,- 572 &, 112 &,- 719 & $-5,116$ &, 000 \\
& KI &, 242 &, 147 & -231 & 1,641 &, 109 \\
DKI & $-1,041$ &, 460 &,- 294 & $-2,264$ &, 029 \\
CI &,- 274 &, 154 &,- 241 & $-1,783$ &, 082 \\
\hline
\end{tabular}

a. Dependent Variable: CETR

Sumber; Data yang diolah menggunakan SPSS 25, 2019.

$$
\mathrm{Y}=8,276-0,572(\mathrm{ROA})+0,242(\mathrm{KI})-1,041(\mathrm{DKI})-0,274(\mathrm{CI})+\mathrm{e}
$$

Nilai konstanta (a) yang dihasilkan berdasarkan hasil regresi linear berganda pada penelitian ini adalah sebesar 8,276. Nilai tersebut memberi arti bahwa koefisien variabel Return On Assets (ROA), Kepemilikan Institusional (KI), Dewan Komisaris Independen (DKI), Intensitas Modal (CI) dianggap tidak ada (0), maka Penghindaran Pajak bernilai positif 8,276.

Koefisien variabel Return On Assets (ROA) adalah sebesar -0,572 menunjukan apabila terjadi peningkatan sebesar 1, maka Penghindaran Pajak akan menurun sebesar 0,572.

Koefisien variabel Kepemilikan Institusional (KI) adalah sebesar 0,242 menunjukan apabila terjadi peningkatan sebesar 1, maka Penghindaran Pajak akan meningkat sebesar 0,242. 
Koefisien variabel Dewan Komisaris Independen (DKI) adalah sebesar -1,041 menunjukan apabila terjadi peningkatan sebesar 1, maka Penghindaran Pajak akan menurun sebesar 1,041.

Koefisien variabel Intensitas Modal (CI) adalah sebesar -0,274 menunjukan apabila terjadi peningkatan sebesar 1, maka Penghindaran Pajak akan menurun sebesar 0,274.

\section{Koefisien Determinasi}

Koefisien determinasi Adjusted $R^{2}$ digunakan untuk mengetahui seberapa jauh kemampuan model dalam menerangkan variasi variabel dependen (Ghozali, 2012) nilai koefisien determinasi adalah antara nol dan satu.

Tabel 7. Koefisien Determinasi Model Summaryb

\begin{tabular}{lrrrr}
\hline Model & $\mathrm{R}$ & R Square & $\begin{array}{c}\text { Adjusted R } \\
\text { Square }\end{array}$ & $\begin{array}{c}\text { Std. Error of the } \\
\text { Estimate }\end{array}$ \\
\hline 1 &, $635^{\mathrm{a}}$ &, 403 & 343 &, 79051 \\
\hline
\end{tabular}

a. Predictors: (Constant), ROA, KI, DKI, CI

b. Dependent Variable: CETR

Sumber; Data yang diolah menggunakan SPSS 25, 2019.

Berdasarkan tabel diatas diperoleh nilai Adjusted $R$ Square sebesar 0,343 atau 34,3\%. Hal tersebut dapat diartikan bahwa pengaruh variabel independent yaitu Return On Assets (ROA), Kepemilikan Institusional (KI), Dewan Komisaris Independen (DKI), Intensitas Modal (CI) terhadap Penghindaran Pajak sebesar 34,3\% sedangkan sisanya dipengaruhi oleh faktor lain yang tidak masuk dalam model penelitian.

\section{Pengujian Hipotesis}

\section{Uji Parsial}

Uji statistik $\mathrm{t}$ dilakukan untuk mengetahui pengaruh dari masing-masing variabel independen terhadap variabel dependen. Variabel independen secara individual akan mempengaruhi variabel dependen (Ghozali, 2012).

\section{Tabel 8. Uji Parsial}

Coefficients ${ }^{a}$

\begin{tabular}{|c|c|c|c|c|c|c|}
\hline \multirow[b]{2}{*}{ Mode } & & \multicolumn{2}{|c|}{$\begin{array}{l}\text { Unstandardized } \\
\text { Coefficients }\end{array}$} & \multirow{2}{*}{$\begin{array}{c}\text { Standardized } \\
\text { Coefficients } \\
\text { Beta }\end{array}$} & \multirow[b]{2}{*}{$\mathrm{t}$} & \multirow[b]{2}{*}{ Sig. } \\
\hline & & B & Std. Error & & & \\
\hline \multirow[t]{5}{*}{1} & (Constant) & 8,276 & 1,803 & & 4,591 & ,000 \\
\hline & ROA &,- 572 & 112 &,- 719 & $-5,116$ & ,000 \\
\hline & KI & 242 & 147 & 231 & 1,641 & 109 \\
\hline & DKI & $-1,041$ & 460 &,- 294 & $-2,264$ & ,029 \\
\hline & CI &,- 274 & 154 &,- 241 & $-1,783$ & ,082 \\
\hline
\end{tabular}

a. Dependent Variable: CETR

Sumber; Data yang diolah menggunakan SPSS 25, 2019. 
Berdasarkan hasil uji $\mathrm{t}$ pada tabel diatas bahwa nilai $\mathrm{t}$ hitung sebesar $-5,116$ lebih kecil dari $\mathrm{t}$ tabel $2.01954(-5,116<2.01954)$. Dilihat dari nilai signifikansi ROA memiliki nilai $0,000<a=$ 0,05, maka hasil tersebut menunjukan bahwa Return On Assets berpengaruh negatif terhadap Penghindaran Pajak.

Berdasarkan hasil uji $\mathrm{t}$ pada tabel diatas bahwa nilai $\mathrm{t}$ hitung sebesar 1,641 lebih kecil dari $\mathrm{t}$ tabel $2.01954(1,641<2.01954)$. Dilihat dari nilai signifikansi KI memiliki nilai 0,109> $a=0,05$, maka hasil tersebut menunjukan bahwa Kepemilikan Institusional tidak berpengaruh terhadap Penghindaran Pajak.

Berdasarkan hasil uji $\mathrm{t}$ pada tabel diatas bahwa nilai $\mathrm{t}$ hitung sebesar -2,264 lebih kecil dari $\mathrm{t}$ tabel $2.01954(-2,264<2.01954)$. Dilihat dari nilai signifikansi DKI memiliki nilai $0,029<a=$ 0,05, maka hasil tersebut menunjukan bahwa Dewan Komisaris Independen berpengaruh negatif terhadap Penghindaran Pajak.

Berdasarkan hasil uji $\mathrm{t}$ pada tabel diatas bahwa nilai $\mathrm{t}$ hitung sebesar $-1,783$ lebih kecil dari $\mathrm{t}$ tabel 2.01954 $(-1,783<2.01954)$. Dilihat dari nilai signifikansi CI memiliki nilai $0,082>a=0,05$, maka hasil tersebut menunjukan bahwa Intensitas Modal tidak berpengaruh terhadap Penghindaran Pajak.

\section{Uji Simultan}

Uji statistik F pada dasarnya menunjukkan apakah semua variabel independen atau bebas mempunyai pengaruh terhadap variabel dependen atau terikat (Ghozali, 2012). Kriteria pengambilan keputusan pada uji statistik $\mathrm{F}$ adalah dengan membandingkan $\mathrm{F}$ hitung $>$ nilai $\mathrm{F}$ tabel pada $\alpha=5 \%$, maka semua variabel independen secara serentak atau bersama-sama dan signifikan mempengaruhi variabel dependen (Ghozali, 2013: 98).

Tabel 9. Uji Simultan ANOVA $^{a}$

\begin{tabular}{llrrrrr}
\hline & & Sum of & \multicolumn{3}{c}{ Mean } \\
Model & Squares & df & & Square & \multicolumn{1}{c}{ F } & Sig. \\
\hline 1 & Regression & 16,857 & 4 & 4,214 & 6,744 &, $000^{\mathrm{b}}$ \\
& Residual & 24,996 & 40 &, 625 & & \\
& Total & 41,854 & 44 & & & \\
\hline
\end{tabular}

a. Dependent Variable: CETR

b. Predictors: (Constant), ROA, KI, DKI, CI

Sumber; Data yang diolah menggunakan SPSS 25, 2019.

Berdasarkan tabel diatas, output hasil uji simultan persamaan regresi diperoleh $\mathrm{F}$ hitung sebesar 6,744 dengan nilai signifikan sebesar 0.000, karena nilai F hitung 6,744 > F tabel 2.83 dan nilai signifikan 0,000 < sig $a=0,05$, maka dapat disimpulkan bahwa Return On Assets (ROA), Kepemilikan Institusional (KI), Dewan Komisaris Independen (DKI), dan Intensitas Modal (CI) secara simultan berpengaruh terhadap Penghindaran Pajak.

\section{Pengaruh Return On Assets Terhadap Penghindaran Pajak}

Return On Assets (X1) memiliki pengaruh negatif terhadap penghindaran pajak. Hasil penelitian ini mendukung penelitian sebelumnya oleh Maharani, dkk (2014) dan Arianandini, dkk (2018) yang menyatakan bahwa Return On Assets berpengaruh negatif terhadap tax avoidance. Hal ini berarti Return On Assets merupakan satu indikator yang mencerminkan 
performa keuangan perusahaan, semakin tinggi nilai Return On Assets maka akan semakin baik performa perusahaan tersebut. Perusahaan yang memperoleh laba diasumsikan tidak melakukan tax avoidance karena mampu mengatur pendapatan dan pembayaran pajaknya.

Hasil penelitian ini tidak sejalan dengan penelitian yang dilakukan oleh Hidayah, dkk (2017) yang menyatakan bahwa Return On Assets tidak berpengaruh signifikan terhadap tax avoidance. Hal ini berarti disebabkan karena semakin tinggi niali ROA akan dilakukan parencanaan pajak yang matang sehingga menghasilkan pajak yang optimal dan aktivitas tax avoidance akan mengalami penurunan. Perusahaan yang beroperasi dengan efisiensi tinggi akan mendapatkan tax subsidy berupa tarif pajak efektif yang lebih rendah dibandingkan dengan perusahaan yang beroperasi dengan efisiensi rendah. Jadi semakin tinggi nilai ROA tidak mempengaruhi aktivitas tax avoidance.

\section{Pengaruh Kepemilikan Institusional Terhadap Penghindaran Pajak}

Kepemilikan institusional (X2) tidak berpengaruh terhadap penghindaran pajak. Hasil penelitian ini mendukung penelitian sebelumnya oleh Fajar (2018) dan Tandean (2015) yang menyatakan bahwa kepemilikan institusional tidak berpengaruh terhadap penghindaran pajak. Hal ini berarti kepemilikan institusional tidak berperan dalam memantau, mendisiplinkan dan mempengaruhi tindakan oportunis manajer dan pemilik institusional lebih mementingkan untuk memaksimalkan kesejahteraannya dalam meningkatkan laba sehingga besar atau kecilnya kepemilikan institusional tidak mempengaruhi tax avoidance.

Hasil penelitian ini tidak sejalan dengan penelitian yang dilakukan oleh Subagiastra, dkk (2016) yang menyatakan bahwa Kepemilikan Institusional berpengaruh positif terhadap penghindaran pajak. Hal ini berarti kepemilikan institusional memegang peranan yang penting dalam memonitor manajemen perusahaan dengan adanya kepemilikan institusional akan meningkatkan pengawasan yang lebih optimal, yang tentunya akan menjamin kemakmuran pemegang saham. Perusahaan yang memiliki kepemilikan institusional yang tinggi akan semakin agresif dalam meminimalisir pelaporan perpajakan.

\section{Pengaruh Dewan Komisaris Independen Terhadap Penghindaran Pajak}

Dewan Komisaris Independen (X3) berpengaruh negatif terhadap penghindaran pajak. Hasil penelitian ini mendukung penelitian sebelumnya oleh Maharani, dkk (2014) yang menyatakan bahwa dewan komisaris independen berpengaruh negatif terhadap tax avoidance. Hal ini berarti keberadaan dewan komisaris independen efektif dalam usaha mencegah tindakan penghindaran pajak. Proporsi dewan komisaris independen dalam perusahaan dapat menurunkan tindakan penghindaran pajak, semakin besar atau tinggi dewan komisaris independen berarti semakin banyak juga suatu perusahaan memiliki dewan komisaris independen sehingga kebijakan tax avoidance semakin menurun.

Hasil penelitian ini tidak sejalan dengan penelitian yang dilakukan oleh Syuhanda, dkk (2019) yang menyatakan bahwa dewan komisaris independen tidak berpengaruh signifikan terhadap Tax Avoidance. Hal ini berarti banyak atau sedikitnya dewan komisaris independen disuatu perusahaan tidak mempengaruhi terhadap tindakan tax avoidance yang dilakukan oleh perusahaan. Keberadaan dewan komisaris independen dalam perusahaan hanya sebagai pengawasan dan memastikan bahwa perusahaan telah mematuhi peraturan dengan baik, dewan komisaris independen tidak turut serta dalam mengambil keputusan operasional perusahaan dengan demikian dewan komisaris independen tidak berpengaruh terhadap Tax Avoidance.

\section{Pengaruh Intensitas Modal Terhadap Penghindaran Pajak}


Capital Intensity (X4) tidak berpengaruh terhadap penghindaran pajak. Hasil penelitian ini mendukung penelitian sebelumnya oleh Wiguna, dkk (2017) yang menyatakan bahwa capital intensity tidak berpengaruh terhadap penghindaran pajak. Hal ini berarti tidak ada pengaruh jumlah aset tetap yang besar terhadap tindakan penghindaran pajak yang dilakukan perusahaan. Tidak adanya pengaruh dari jumlah aset tetap yang dimiliki perusahaan diakibatkan oleh perusahaan dengan jumlah aset tetap yang besar memang menggunakan aset tetap tersebut untuk kepentingan perusahaan, yaitu menunjang kegiatan operasional perusahaan yang digunakan untuk penyediaan barang dan jasa.

Hasil penelitian ini tidak sejalan dengan penelitian yang dilakukan oleh Dharma, dkk (2017) dan Anindyka, dkk (2018) yang menyatakan bahwa capital intensity berpengaruh positif signifikan terhadap tax avoidance. Hal ini berarti semakin besar intensitas aset tetap suatu perusahaan, semakin besar praktek penghindaran pajak pada perusahaan, karena perusahaan yang memiliki aset tetap akan terdapat beban penyusutan atau beban depresiasi yang dapat menjadi pengurang laba sebelum pajak. Sehingga perusahaan akan memanfaatkan aset tetap untuk meminimalkan beban pajak dengan cara menginvestasikan aset tetap pada perusahaan.

\section{Penutup dan Saran}

\section{Simpulan}

Return On Assets berpengaruh negatif terhadap penghindaran pajak. Perusahaan yang memperoleh laba yang tinggi diasumsikan tidak melakukan tax avoidance karena mampu mengatur pendapatan dan pembayaran pajaknya. Kepemilikan institusional tidak berpengaruh terhadap penghindaran pajak, Kepemilikan institusional lebih mementingkan dalam memaksimalkan kesejahteraannya untuk menghasilkan laba yang diperoleh perusahaan sehingga besar kecilnya kepemilikan institusional tidak mempengaruhi tax avoidance. Dewan Komisaris Independen berpengaruh negatif terhadap penghindaran pajak. Dewan komisaris independen dalam perusahaan dapat menurunkan tindakan penghindaran pajak, semakin besar prosentase dewan komisaris independen maka semakin efektif untuk melakukan pengawasan dan pengendalian terhadap kinerja manajer dalam sebuah perusahaan dan Intensitas Modal tidak berpengaruh terhadap penghindaran pajak. Perusahaan yang memiliki asset tetap yang besar tidak digunakan sebagai pengurang pajak melainkan untuk menunjang kegiatan operasional perusahaan.

\section{Keterbatasan}

1. Penelitian ini hanya di perusahaan pertambangan sektor batu bara yang terdaftar di Bursa Efek Indonesia (BEI) dan penelitian ini menggunakan jangka waktu pengamatan yang relatif pendek yaitu selama 3 tahun.

2. Penelitian ini menggunakan 3 variabel yaitu Profitabilitas menggunakan satu proksi, Good Corporate Governance menggunakan dua proksi, dan Intensitas Modal menggunakan satu proksi. 


\section{Referensi}

Anindyka, D., Pratomo, D., \& Kurnia, K. (2018). Pengaruh Leverage (Dar), Capital Intensity Dan Inventory Intensity Terhadap Tax Avoidance (Studi Pada Perusahaan Makanan Dan Minuan Di Bursa Efek Indonesia (Bei) Tahun 2011-2015). eProceedings of Management, 5(1).

Dewinta, I. A. R., \& Setiawan, P. E. (2016). Pengaruh ukuran perusahaan, umur perusahaan, profitabilitas, leverage, dan pertumbuhan penjualan terhadap tax avoidance. E-Jurnal Akuntansi Universitas Udayana, 14(3), 1584-1613.

Dharma, N. B. S., \& Noviari, N. (2017). Pengaruh Corporate Social Responsibility dan Capital Intensity Terhadap Tax Avoidance. E-Jurnal Akuntansi Universitas Udayana, 18(1), 529556.

Fajar, M. (2018). Pengaruh Profitabilitas, Leverage, dan Corporate Governance Terhadap Tax Avoidance (Studi Empiris Pada Perusahaan Manufaktur Yang Terdaftar Di Bursa Efek Indonesia Periode 2012-2014). , 1(1).

Fernández-Rodríguez, E., \& Martínez-Arias, A. (2012). Do business characteristics determine an effective tax rate? Evidence for listed companies in China and the United States. Chinese Economy, 45(6), 60-83.

Ghozali, I. (2012). Aplikasi Analisis Multivariate Dengan Program IBM SPSS 25. Semarang: Universitas Diponerogo.

Ghozali, I. (2013). Aplikasi Analisis Multivariate Dengan Program IBM SPSS 25. Semarang: Universitas Diponerogo.

Ghozali, I. (2018). Aplikasi Analisis Multivariate Dengan Program IBM SPSS 25. Semarang: Universitas Diponerogo.

Hanafi, M., \& Halim, A. (2012). Analisis Laporan Keuangan. Yogyakarta: (UPP) STIM YKPN.

Hidayah, R. (2017). Pengaruh Mekanisme Corporate Governance, Risiko Perusahaan dan Return on Asset (ROA) Terhadap Tax Avoidance. Jurnal Ilmiah Neraca FEB-UMPP, 13(2), 52-69.

Maharani, I. G. A. C., \& Suardana, K. A. (2014). Pengaruh corporate governance, profitabilitas dan karakteristik eksekutif pada tax avoidance perusahaan manufaktur. E-Jurnal Akuntansi Universitas Udayana, 9(2), 525-539.

Pohan, C. A. (2013). Manajemen Perpajakan. Jakarta: PT. Gramedia Pustaka Utama.

Santoso, T. B. (2014). Pengaruh Corporaet Governance Terhadap Pengindaran Pajak Perusahaan. Semarang: Universitas Diponegoro.

Subagiastra, K., Arizona, I. P. E., \& Mahaputra, I. N. K. A. (2017). Pengaruh Profitabilitas, Kepemilikan Keluarga, dan Good Corporate Governance Terhadap Penghindaran Pajak (Studi pada Perusahaan Manufaktur di Bursa Efek Indonesia). JIA (Jurnal Ilmiah Akuntansi), 1(2).

Sunarsih, U., \& Handayani, P. (2018). Pengaruh Corporate Governance Terhadap Penghindaran Pajak Pada Perusahaan Manufaktur Yang Terdaftar Di Bursa Efek Indonesia. Jurnal Akuntansi, 12(2), 163-185. 
Syuhada, A., Yusnaini, Y., \& Meirawati, E. (2019). Pengaruh Good Corporate Governance dan Profitabilitas Terhadap Tax Avoidance (Studi Empiris pada Sektor Pertambangan Yang Terdaftar di BEI). Akuntabilitas, 13(2), 127-140.

Undang-Undang Republik Indonesia Nomor 16 Tahun 2009 Tentang Ketentuan Umum dan Tata Cara Perpajakan. Jakarta, Kementrian Keuangan.

Wiguna, P. P., \& Jati, I. K. (2017). Pengaruh Corporate Social Responsibility, Preferensi Risiko Eksekutif, dan Capital Intensity pada Penghindaran Pajak. E-Jurnal Akuntansi Universitas Udayana, 21(1).

Wijayanti, A., Wijayanti, A., \& Chomsatu, Y. (2017). Pengaruh Karaktristik Perusahaan, Good Corporate Governance, dan Corporate Social Responsibility Terhadap Penghindaran Pajak. Journal Of Economic And Economic Education, 5(2), 112-127. 